\title{
The induction of trimethoprim resistance encoded by the type IV dihydrofolate reductase gene
}

\author{
HILARY-KAY YOUNG, C. J. THOMSON* and S. G. B. AMYES* \\ Department of Biological Sciences, University of Dundee, Dundee DD1 4HN and "Department of Medical
Microbiology, The Medical School, University of Edinburgh, Teviot Place, Edinburgh EH8 9AG
}

\begin{abstract}
Summary. The effect of plasmid pUK1123, which confers low level resistance to trimethoprim when tested on solid minimal medium, but almost no resistance when tested on IsoSensitest agar, was investigated in liquid media. The growth of Escherichia coli J62-2, harbouring pUK1123, was unaffected in liquid minimal medium containing trimethoprim $10 \mathrm{mg} / \mathrm{L}$. However, in IsoSensitest broth, exposure to this drug concentration resulted in bacteriostasis. After an initial delay, resistance to trimethoprim was induced in IsoSensitest broth containing trimethoprim $10 \mathrm{mg} / \mathrm{L}$, by the imposition of thymine starvation. This response was immediately reversible when trimethoprim was removed, confirming that resistance resulted from induction rather than selection of resistant mutants.
\end{abstract}

\section{Introduction}

Trimethoprim selectively inhibits bacterial dihydrofolate reductase (EC 1.5.1.3), which catalyses the reduction of dihydrofolate to the active co-factor tetrahydrofolate. ${ }^{1}$ Bacterial resistance to trimethoprim most commonly results from the plasmid- or transposon-directed synthesis of an additional trimethoprim-insensitive dihydrofolate reductase which allows the inhibited host target enzyme to be bypassed. ${ }^{2}$ The MIC of trimethoprim for bacteria harbouring trimethoprim-resistance plasmids ( $R$-plasmids) is usually $>1000 \mathrm{mg} / \mathrm{L}^{3,4}$ although there are reports of $\mathrm{R}$ plasmids conferring only moderate levels of resistance to trimethoprim (MIC 64-250 mg/L). ${ }^{5-8}$

The action of trimethoprim on the bacterial cell can be either bacteriostatic or bactericidal, depending on the composition of the medium. ${ }^{9}$ Sensitive strains of Escherichia coli die rapidly in the presence of trimethoprim if L-methionine, glycine and a purine derivative are present in the medium. This has been compared to "thymineless death" since the effect is reversed by the presence of thymine derivatives. ${ }^{9}$ The effect of L-methionine, glycine and purine derivatives is to preserve the integrity of the tetrahydrofolic acid pool during trimethoprim treatment. This allows protein synthesis to occur, which is essential for the death of the organism. ${ }^{9}$

In 1985 we reported a new type of trimethoprim Rplasmid which confers on $E$. coli hosts only a moderate level of trimethoprim resistance, the extent of which depends on the test agar. ${ }^{10}$ MICs of trimethoprim for

Received 22 Jan. 1992; revised version received 28 Aug. 1992; accepted 4 Sept. 1992. bacteria harbouring these plasmids ranged from $160 \mathrm{mg} / \mathrm{L}$, when measured in minimal medium, to only $5 \mathrm{mg} / \mathrm{L}$ when measured in various complex media. ${ }^{10}$ This results from hyperproduction of a novel dihydrofolate reductase, type IV, encoded by the plasmid and triggered by the metabolic conditions imposed on the cell by trimethoprim, which emulates thymine starvation, rather than by trimethoprim itself. $^{11}$ We now report the in-vitro effect of trimethoprim on $E$. coli $\mathrm{K}-12$ carrying the plasmid pUK 1123 and examine whether hyperproduction of the enzyme results from induction of the resistance mechanism or selection of resistant mutants.

\section{Materials and methods}

\section{Bacterial strains and plasmids}

E. coli $\mathrm{K}-12$ strain $\mathrm{J} 62-2$ (pro his trp), ${ }^{12}$ which is susceptible to trimethoprim, was used as the standard host strain. The R-plasmid pUK1123 was identified in a strain of $E$. coli isolated in South India, and confers resistance to trimethoprim, sulphamethoxazole and streptomycin. $^{13}$

\section{Media}

The minimal medium used was that described by Davis and Mingioli $^{14}$ and was prepared as described by Smith. ${ }^{15}$ The medium was supplemented with Lproline, L-histidine and L-tryptophan (each at $50 \mathrm{mg} / \mathrm{L}$ ) to allow the growth of strain J62-2, and with glucose $0.28 \%$ as the carbon source. The supplements L-methionine, glycine and adenine (each at $50 \mathrm{mg} / \mathrm{L}$ ) 
were added as indicated in the text. The complex medium used was IsoSensitest Broth (CM473; Oxoid) which lacks thymine derivatives and does not antagonise trimethoprim. ${ }^{16}$

\section{Reagents}

Amino acids (Sigma) were sterilised in solution by steaming for $30 \mathrm{~min}$. Adenine (Koch-Light) was ster- ilised by autoclaving. Trimethoprim lactate was a gift from the Wellcome Research Laboratories, Beckenham; results were expressed in terms of the concentration of the trimethoprim base.

\section{Growth experiments in minimal and complex media}

Exponential phase cultures of $E$. coli $\mathrm{J} 62-2$, with and without plasmid pUK1123, were prepared by sub-

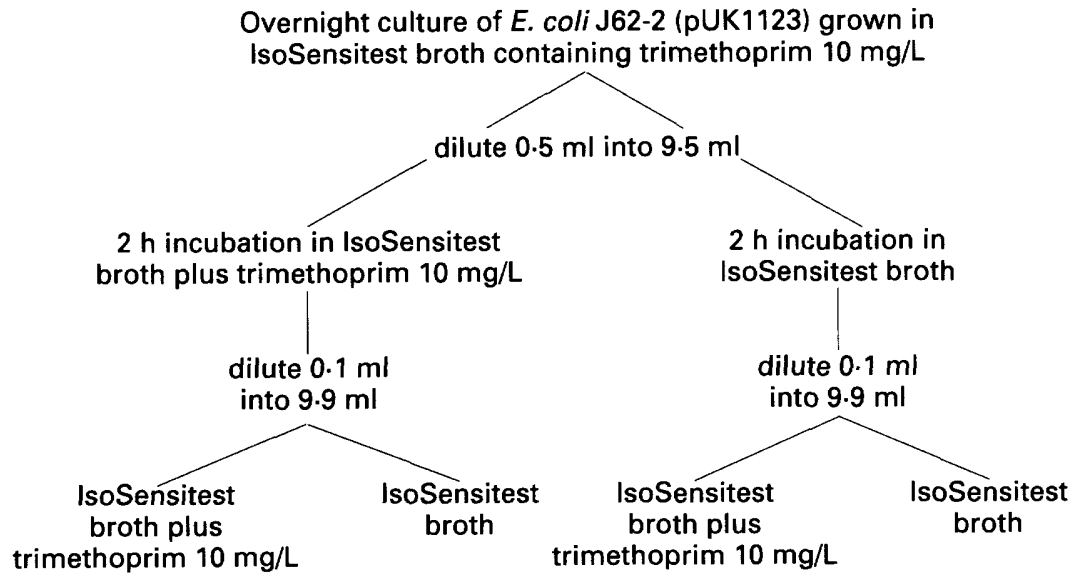

Samples taken every hour for $6 \mathrm{~h}$

Fig. 1. Method to determine whether resistance to trimethoprim results from a genotypic mutation.

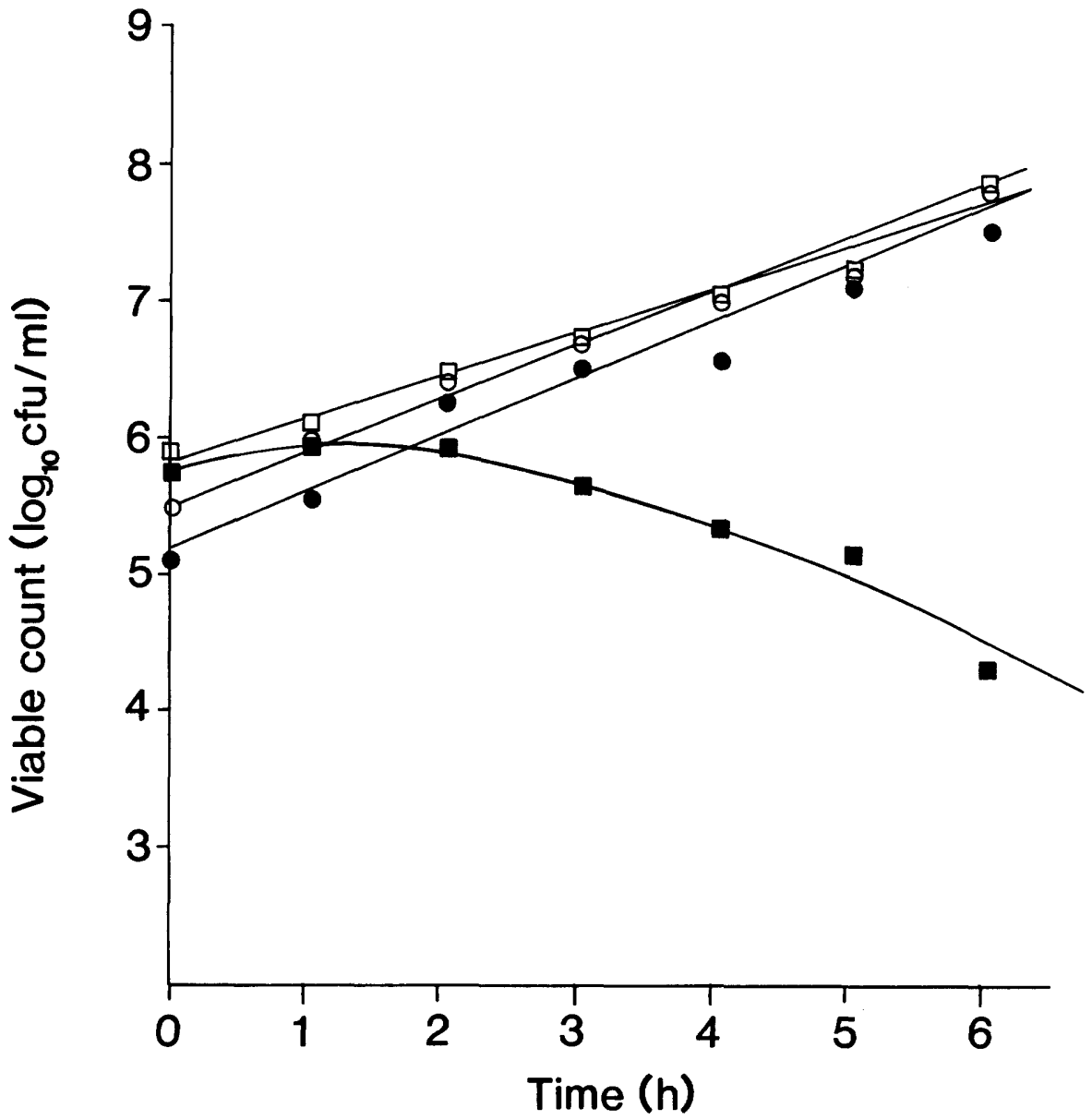

Fig. 2. The effect of plasmid pUK1123 on the growth of $E$. coli $\mathrm{J} 62-2$ in minimal medium. Exponential phase cultures of $E$. coli J62-2 with $(O, \bullet)$ or without $(\square, \square)$ plasmid pUK 1123 were inoculated into minimal medium containing $(\boldsymbol{Q}, \mathbf{\square})$ or lacking $(O, \square)$ trimethoprim $10 \mathrm{mg} / \mathrm{L}$. 


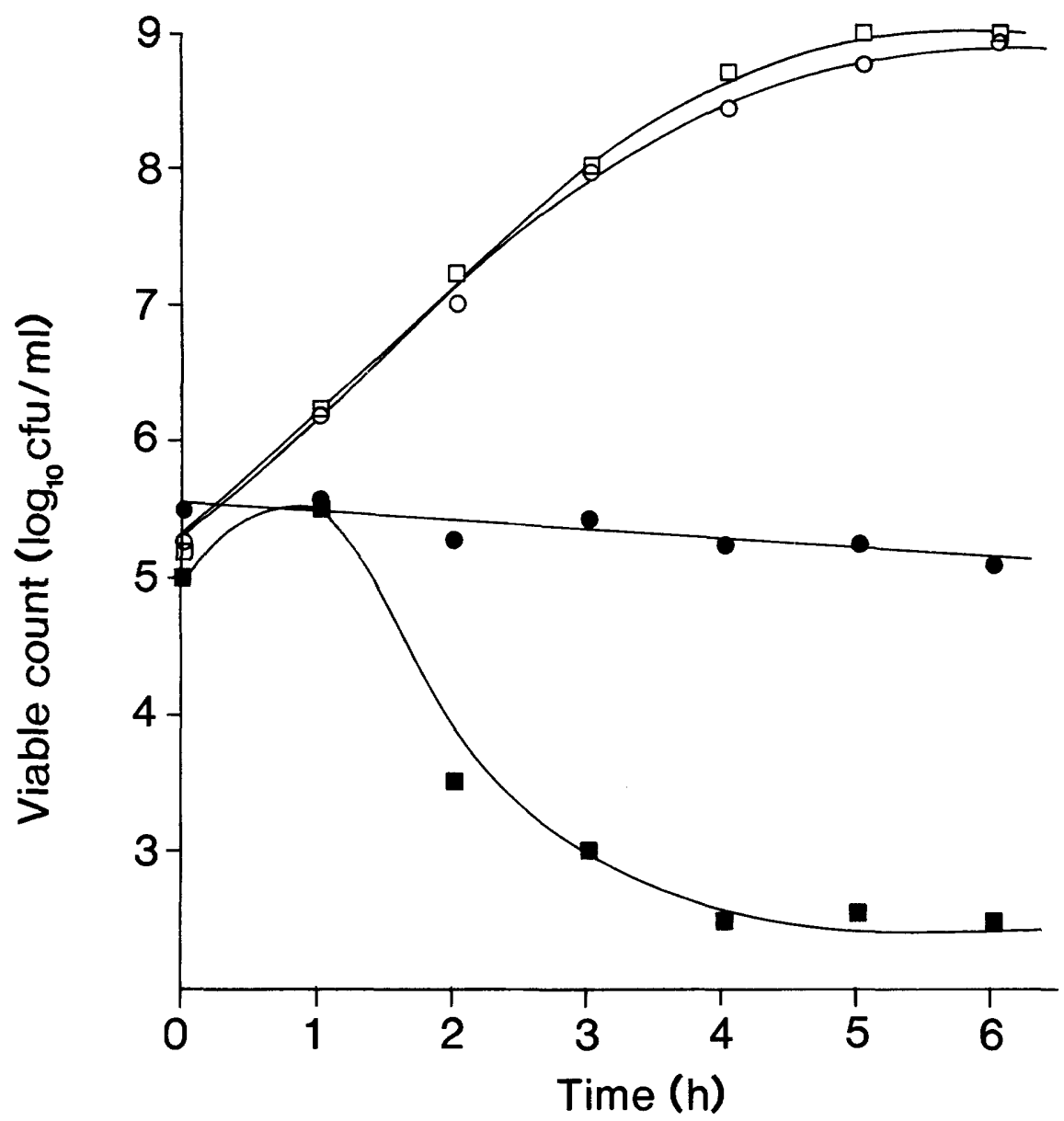

Fig. 3. The effect of plasmid pUK1123 on the growth of $E$. coli J62-2 in IsoSensitest complex medium. Exponential phase cultures of $E$. coli J62-2 with $(O, \bullet)$ or without $(\square, \boldsymbol{\square})$ plasmid pUK1123 were inoculated into complex medium containing $(\bullet, \boldsymbol{Q})$ or lacking $(O, \square)$ trimethoprim $10 \mathrm{mg} / \mathrm{L}$.

culturing $0.5 \mathrm{ml}$ of stationary phase cultures into $9.5 \mathrm{ml}$ of pre-warmed IsoSensitest broth, or appropriately supplemented minimal medium, and incubating for $2 \mathrm{~h}$ at $37^{\circ} \mathrm{C}$ in an orbital incubator. These cultures $(0.1 \mathrm{ml})$ were then diluted into $9.9 \mathrm{ml}$ of suitably supplemented pre-warmed media, with and without trimethoprim $10 \mathrm{mg} / \mathrm{L}$, and incubated statically at $37^{\circ} \mathrm{C}$. Samples were taken every hour for $6 \mathrm{~h}$ and the viable count was estimated by plating serial dilutions (in minimal medium) on MacConkey Agar (CM7b, Oxoid). The plates were incubated at $37^{\circ} \mathrm{C}$ for $18 \mathrm{~h}$ and the resultant colonies were counted.

To investigate the effect of pre-exposure to trimethoprim, E. coli J62-2 (pUK1123) was grown overnight in IsoSensitest broth containing trimethoprim $10 \mathrm{mg} / \mathrm{L}$ and then diluted into pre-warmed IsoSensitest broth with or without trimethoprim. After incubation at $37^{\circ} \mathrm{C}$ for $2 \mathrm{~h}$, the cultures were again diluted into IsoSensitest broth either with or without trimethoprim (fig. 1). The viable count was monitored for $6 \mathrm{~h}$ as before. As a control, identical procedures were applied to E. coli J62-2 lacking the plasmid except that this strain was grown initially overnight in the absence of trimethoprim.

\section{Results and discussion}

Bacteria were challenged with trimethoprim $10 \mathrm{mg} / \mathrm{L}$, since this concentration caused hyperproduction of the type IV dihydrofolate reductase but had only a small effect on cell viability.

\section{Growth response in minimal and complex media}

A very gradual reduction in viable count was observed after subculture of $E$. coli $\mathrm{J} 62-2$ into minimal medium containing trimethoprim $10 \mathrm{mg} / \mathrm{L}$. When plasmid pUK1123 was present in the strain, the bacteria multiplied at a rate similar to that observed in medium without trimethoprim (fig. 2). In IsoSensitest broth, the control strain died rapidly in the presence of trimethoprim, but the strain harbouring the plasmid was merely inhibited by trimethoprim $10 \mathrm{mg} / \mathrm{L}$ (fig. 3). Thus, in complex medium trimethoprim had a bacteriostatic effect on cells harbouring pUK1123; whereas in minimal medium the plasmid offered full protection. 


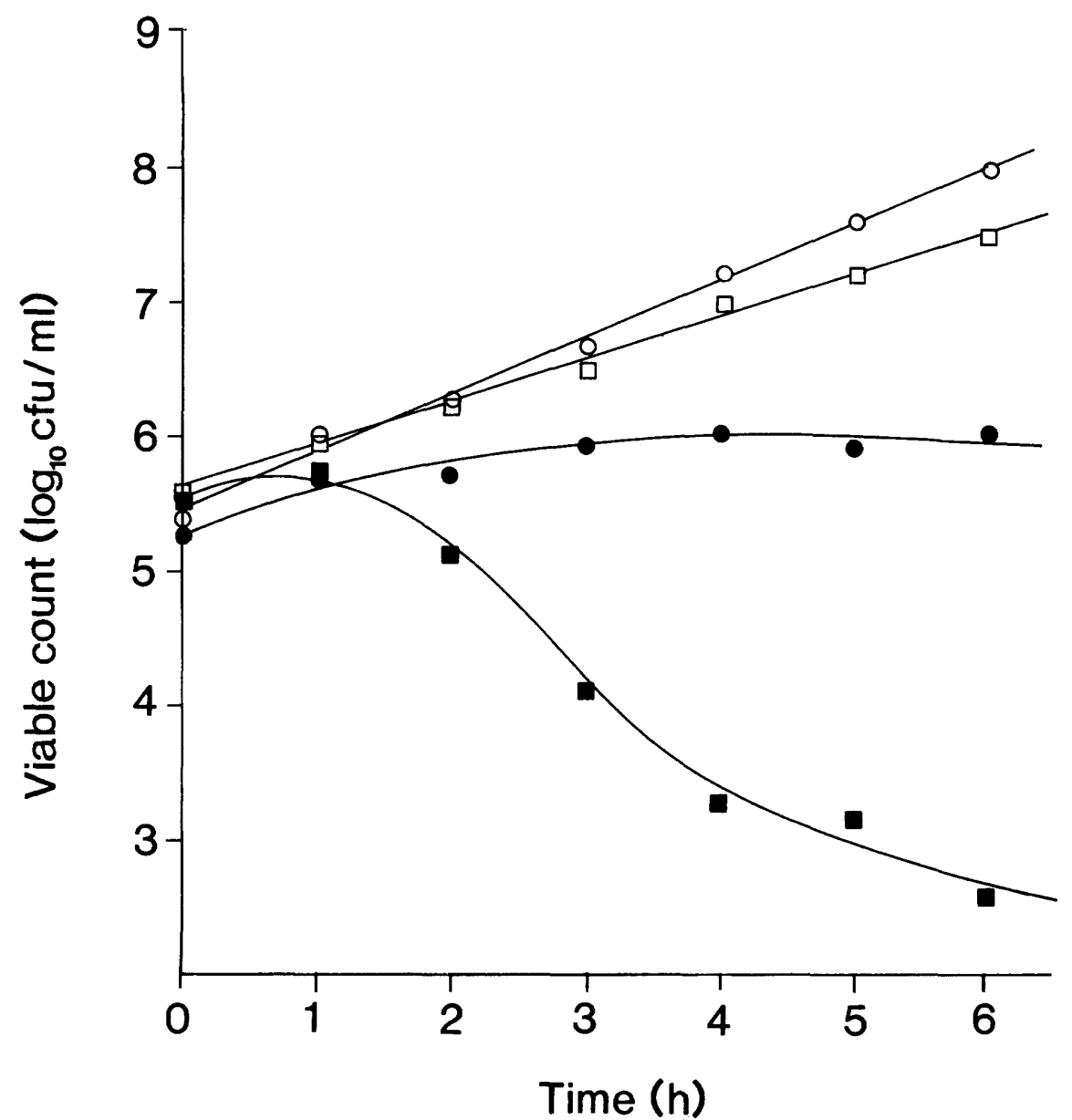

Fig. 4. The effect of plasmid pUK1123 on the growth of E. coli J62-2 in minimal medium containing L-methionine, glycine and adenine. Exponential phase cultures of $E$. coli $\mathrm{J} 62-2$ with $(O, \boldsymbol{O})$ or without $(\square, \boldsymbol{\square})$ plasmid pUK1123 were inoculated into supplemented minimal medium containing $(\boldsymbol{\square})$ or lacking $(O, \square)$ trimethoprim $10 \mathrm{mg} / \mathrm{L}$.

\section{Investigation of the bacteriostatic nature of trimethoprim}

Since the response of plasmid-free bacteria to trimethoprim depends on the presence of L-methionine, glycine and purine derivatives in the medium, ${ }^{9}$ the growth of bacteria harbouring pUK1123 was examined in minimal medium to which these defined supplements had been added. In this medium trimethoprim caused bacteriostasis of $E$. coli J62-2 (pUK1123) similar to that observed in IsoSensitest broth, but with very slight growth of the bacteria (fig. 4). Thus, other supplement(s) may be required to cause complete bacteriostasis.

\section{Mode of trimethoprim resistance mediated by plasmid} pUK1123

On prolonged incubation, without shaking, at $37^{\circ} \mathrm{C}$ for a further $16 \mathrm{~h} \mathrm{E}$. coli J62-2 (pUK1123) multiplied in IsoSensitest broth containing trimethoprim to give a viable count of $c .10^{8} \mathrm{cfu} / \mathrm{ml}$, whereas the viable count of the strains lacking the plasmid, grown under similar conditions, was only $10^{4} \mathrm{cfu} / \mathrm{ml}$.

There are two possible explanations for this observation: either a genetic mutant, resistant to tri- methoprim $10 \mathrm{mg} / \mathrm{L}$, had evolved and was selected in the presence of trimethoprim, or phenotypic adaptation to the presence of the drug had occurred. In order to test which of these two possibilities was correct, the effect of removing the trimethoprim pressure for $2 \mathrm{~h}$ was investigated (fig. 1).

Bacteria harbouring plasmid pUK 1123 and grown continuously in the presence of trimethoprim in complex medium grew at a similar rate in the presence and absence of trimethoprim after subculture into fresh broth (fig. 5). In contrast, bacteria which had been subcultured into medium lacking trimethoprim for only $2 \mathrm{~h}$ reverted to their original phenotype, showing a bacteriostatic response to subsequent challenge with trimethoprim (fig. 6). E. coli J62-2, lacking the plasmid, was killed by trimethoprim, regardless of whether the strain had (fig. 5) or had not (fig. 6) been continuously exposed to the drug. These results suggest that resistance is induced by trimethoprim in the plasmid-containing strain.

The trimethoprim R-plasmid pUK 1123 confers only a moderate level of resistance on its host. This depends on the composition of the medium, with almost negligible resistance being conferred on solid complex media. ${ }^{10}$ The present results show that the presence of plasmid pUK1123 in E. coli permits the bacteria to 


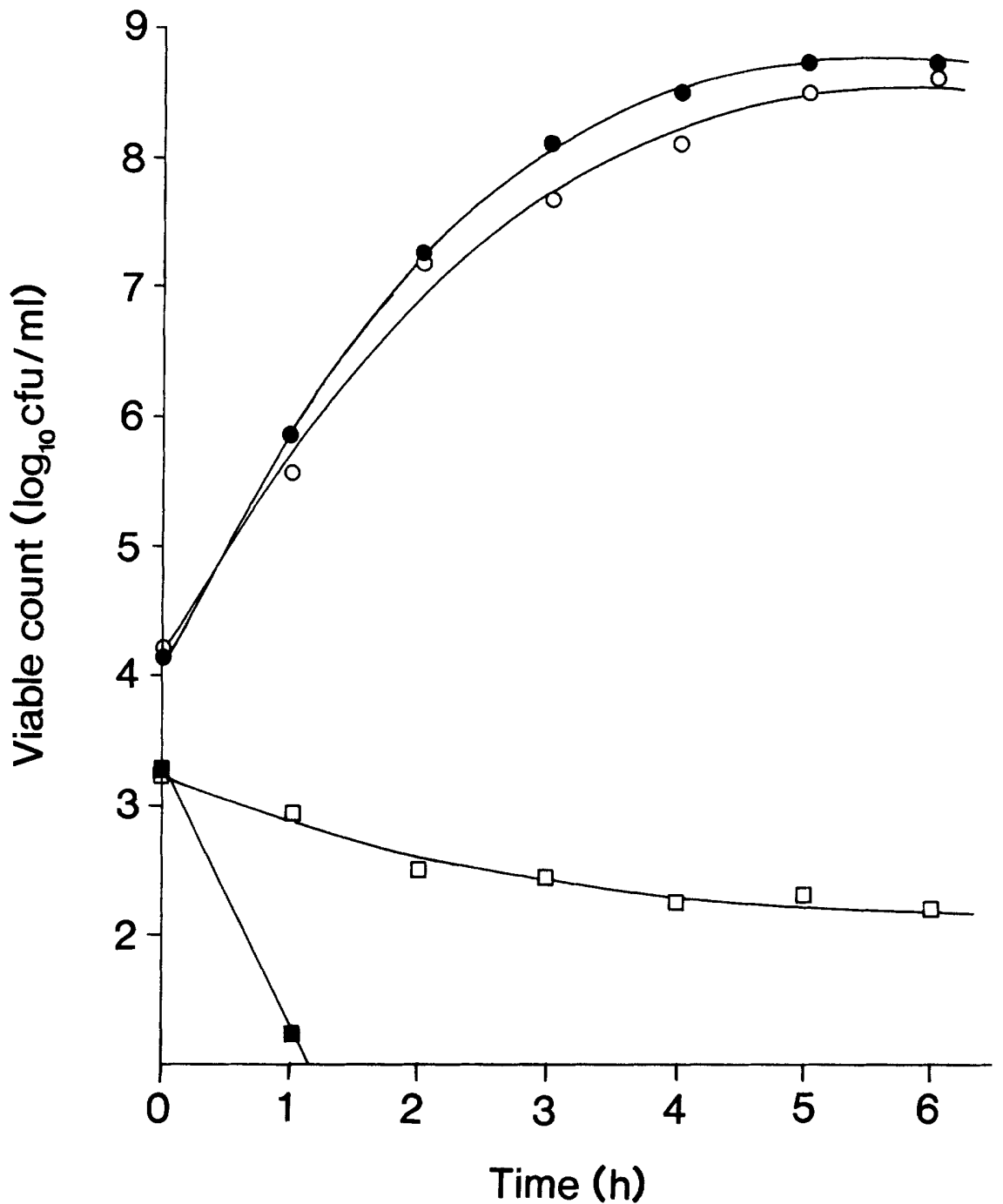

Fig. 5. The effect of plasmid pUK1123 on the growth of $E$. coli J62-2 in IsoSensitest broth after continuous challenge with trimethoprim. Overnight cultures of $E$. coli J62-2 (pUK1123) grown in the presence of trimethoprim $10 \mathrm{mg} / \mathrm{L}$ were diluted and grown for a further $2 \mathrm{~h}$ in IsoSensitest broth containing trimethoprim $10 \mathrm{mg} / \mathrm{L}$. This culture was then diluted into IsoSensitest broth containing $(O)$ or lacking $(O)$ trimethoprim $10 \mathrm{mg} / \mathrm{L}$. Control cultures of $E$. coli J62-2 were similarly diluted into IsoSensitest broth containing ( $\square$ ) or lacking ( $\square$ ) trimethoprim.

grow apparently unaffected in liquid minimal medium containing trimethoprim $10 \mathrm{mg} / \mathrm{L}$. This suggests that conventional methods of sensitivity testing on agar plates would not reflect the true response to trimethoprim of bacteria harbouring plasmid pUK1123. In IsoSensitest broth, the initial effect of the plasmid was to allow its bacterial host merely to survive, without multiplication, in the presence of trimethoprim. Experiments in supplemented minimal medium revealed that this response resulted from the presence of L-methionine, glycine and adenine in IsoSensitest broth.

Trimethoprim resistance mediated by plasmid pUK 1123 results from the production of an inducible plasmid-encoded dihydrofolate reductase which is only slightly resistant to trimethoprim $(\mathrm{Ki}=63 \mathrm{nM}) .{ }^{17}$ The basal level of production of this enzyme is about four times that of the sensitive host chromosomal enzyme and a 12-fold increase occurs in the presence of trimethoprim $10 \mathrm{mg} / \mathrm{L} .{ }^{17}$ The presence of this resistant enzyme explains the ability of organisms harbouring plasmid pUK 1123 to remain viable in complex media containing trimethoprim, and induced synthesis of the enzyme in the presence of trimethoprim offers an explanation for the subsequent growth observed following trimethoprim challenge.

The type IV enzyme has been detected only in South India but appears to be still common there 5 years after the original isolations. ${ }^{18}$ It is tempting to speculate that such an unusual resistance mechanism may be the result of conditions prevalent in the Third World, namely frequent intermittent low dosing with trimethoprim in combination with frequent infections. It is not difficult to imagine how the type IV enzyme could be successful in these conditions, especially if located on the same plasmid as other resistance genes. Bacteria containing transferable low-level resistance to trimethoprim have also been isolated from healthy subjects in Nigeria, although it is not known if this results from a type IV-like enzyme. ${ }^{19}$ 


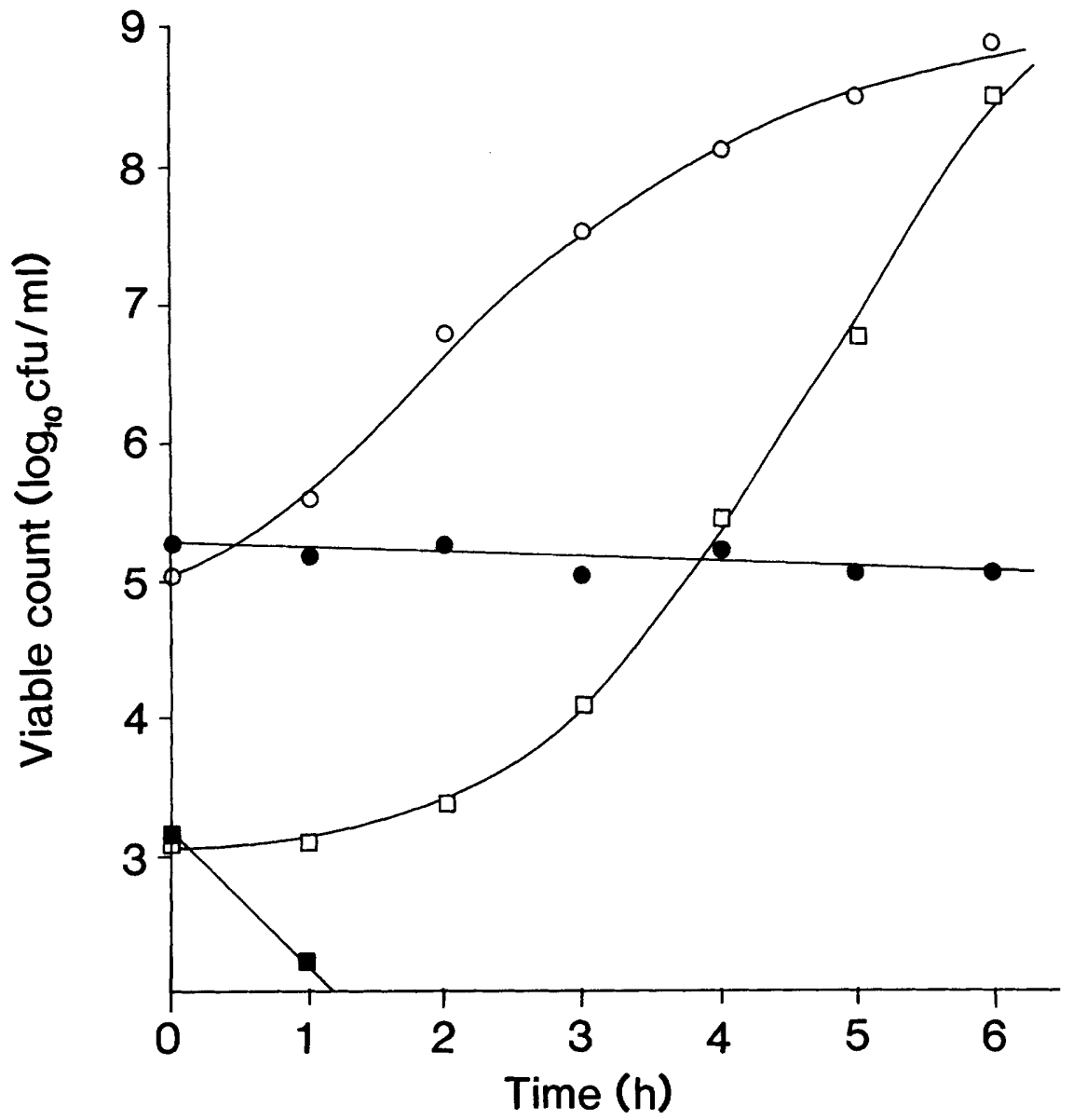

Fig. 6. The effect of plasmid pUK1123 on the growth of E. coli J62-2 in IsoSensitest broth after the temporary removal of trimethoprim challenge. Cultures of $E$. coli J62-2 (pUK1123) were grown overnight in the presence of trimethoprim $10 \mathrm{mg} / \mathrm{L}$ and were then cultured for $2 \mathrm{~h}$ in the absence of the drug. They were diluted into IsoSensitest broth containing (O) or lacking $(O)$ trimethoprim $10 \mathrm{mg} / \mathrm{L}$. Control cultures of E. coli J62-2 were similarly diluted into IsoSensitest broth containing ( $\boldsymbol{\square})$ or lacking $(\square)$ trimethoprim.

We thank the Wellcome Trust for grant no. 16376/1.5 which funded this project. We are very grateful to Professor M. V. Jesudason of the Microbiology Department at the Christian Medical College Hospital, Vellore, India for helping us obtain the original E. coli strain harbouring plasmid pUK1123.

\section{References}

1. Burchall JJ, Hitchings GH. Inhibitor binding analysis of dihydrofolate reductases from various species. Mol Pharmacol 1965; 1: 126-136.

2. Amyes SGB, Smith JT. R-factor trimethoprim resistance mechanism: an insusceptible target site. Biochem Biophys Res Commun 1974; 58: 412-418.

3. Fleming MP, Datta N, Grüneberg RN. Trimethoprim resistance determined by $\mathrm{R}$ factors. $B M J 1972 ; 1: 726-728$.

4. Datta N, Hedges RW. Trimethoprim resistance conferred by W plasmids in Enterobacteriaceae. J Gen Microbiol 1972; 72: 349-355.

5. Towner KJ, Pinn PA. A transferable plasmid conferring only a moderate level of resistance to trimethoprim. FEMS Microbiol Lett 1981; 10: 271-272.

6. Fling ME, Walton L, Elwell LP. Monitoring of plasmidencoded, trimethoprim-resistant dihydrofolate reductase genes: detection of a new resistant enzyme. Antimicrob Agents Chemother 1982; 22: 882-888.

7. Barg NL, Hutson FS, Wheeler LA et al. Novel dihydrofolate reductases isolated from epidemic strains of trimetho$\mathrm{prim} / \mathrm{sulfamethoxazole-resistant} \mathrm{Shigella}$ sonnei. $J$ Infect Dis 1990 ; 162: 466-473.

8. Thomson CJ, Towner KJ, Young H-K, Amyes SGB Identification and cloning of the Type IIIa plasmidencoded dihydrofolate reductase from trimethoprim- resistant gram-negative bacteria isolated in Britain. $J$ Med Microbiol 1990; 31: 213-218.

9. Amyes SGB, Smith JT. Trimethoprim action and its analogy with thymine starvation. Antimicrob Agents Chemother 1974; 5: 169-178.

10. Young H-K, Jesudason MV, Koshi GK, Amyes SGB. Unusual expression of new low-level-trimethoprim-resistance plasmids. J Clin Microbiol 1986; 24: 61-64.

11. Thomson CJ, Young H-K, Amyes SGB. The role of thymine starvation in the expression of the type IV plasmid-encoded trimethoprim-resistant dihydrofolate reductase. $J$ Med Microbiol 38: 250-255.

12. Bachmann BJ. Pedigrees of some mutant strains of Escherichia coli K-12. Bacteriol Rev 1972; 36: 525-557.

13. Young H-K, Jesudason MV, Koshi G, Amyes SGB. Trimethoprim resistance amongst urinary pathogens in South India. J Antimicrob Chemother 1986; 17: 615-621.

14. Davis BD, Mingioli ES. Mutants of Escherichia coli requiring methionine or vitamin $B_{12}$. J Bacteriol 1950; 60: 17-28.

15. Smith JT. R-factor gene expression in gram-negative bacteria. $J$ Gen Microbiol 1969; 55: 109-120.

16. Amyes SGB, Smith JT. Trimethoprim antagonists: effect of uridine in laboratory media. $J$ Antimicrob Chemother 1978; 4: $421-429$.

17. Young H-K, Amyes SGB. A new mechanism of plasmid trimethoprim resistance: characterization of an inducible dihydrofolate reductase. $J$ Biol Chem 1986; 261: 2503-2505.

18. Amyes SGB, Tait S, Thomson CJ et al. The incidence of antibiotic resistance in aerobic faecal flora in South India. $J$ Antimicrob Chemother 1992; 29: 415-425.

19. Lamikanra A, Fayinka ST, Olusanya OO. Transfer of low level trimethoprim resistance in faecal isolates obtained from apparently healthy Nigerian students. FEMS Microbiol Lett 1989; 59: 275-278. 